
$\mathfrak{A}_{m}$ Shluffe diefes Bandes befindet (id) ein

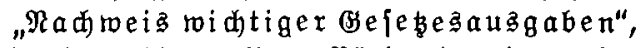
in bem bie meiften Bänbe ber je über

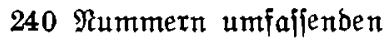

\section{Guttentag|hen Sammlung}

\section{Bentfder Leidis: und Breufifher Befetse}

D forwie größzere und fleinere fommentare, Lehr. büber, Sammelwerle, Entideibungşumm= Iungen und Beitidriften verzeidnet find. 


\section{(5)

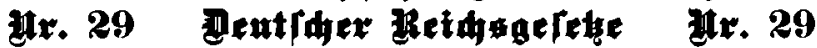 Rommentare und exläuterte Tertausapaben}

\section{Das Reidbgefes, betreffend bie

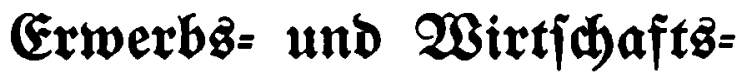 genofjenjaditen}

Tetrtauảgabe mit $\mathfrak{A}$ mmerfungen und Sachregifter bon

Qubolf Parifus und Dr. \$̧ans Crüger (ipäter Dr. \$ans (Crüger und Dr. XDolf (Erecelius)

Einundzwanzigite, nen bearbeitete und erweiterte Auflage (93.-98. Taujenb)

von

Oberverwaltungsిgerichtąnat Grik Citron

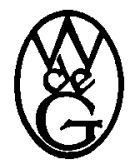

Berlinund $\mathfrak{L}$ eipzig 1933

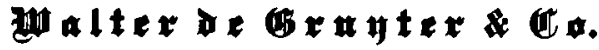

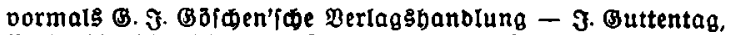
Berlagsbudbanblung - Beorg Hetmer - Sarl Э. Trabner Bett \& comp. 
Urd)=ykr.: 211029 